\title{
19 Strong walls for an open faith
}

\author{
Francis X. Clooney, SJ
}

The Catholic tradition throughout history shows us how confessional commitments provide a solid foundation for finding God present in the wide world around us. The Church is, briefly put, catholic (global, worldwide) as well as Catholic (an institution centered in Rome); but if it is not Catholic, it ceases also to be catholic. I admit that the Church's narrative of itself is tainted with self-regard and rarely leaves room for the full self-articulation of the other. Nevertheless, there is a distinctive Catholic dynamic: the universal in tension with the particular (the Catholic and the catholic), a hierarchical tradition with settled doctrines, a commitment to rational and systematizing inquiry alongside openness to the imaginative and intuitive, the freedom of the individual amid a strongly ordered community. This dynamic provided a fertile ground wherein interreligious learning can occur, because of the specificity of the Catholic manner of being in the world and not despite it. This firm structure - support walls, floors and roofs, doors and windows - has a contribution to make in an interreligious context, and indeed is arguably preferable to the ideal of an entirely open space.

\section{A great tradition}

In this short space, the best way to proceed is by hearkening to the great story the Church tells about itself, even if this story, like any such fond account, is best heard with a touch of skepticism.

As the Church thinks of itself, its history is a history of accommodation and engagement with cultures. The history of Israel combined a strong sense of vocation with endless engagement with surrounding cultures and with all the virtues and pitfalls of trying to balance openness and fidelity. The Church of which I speak is, of course, the Roman Catholic Church, which moved from its Jewish roots to an engagement with Greek and Roman cultures. The empire was hostile to the Christian message, but then became the vehicle of Christian identity and community. The Church was, from its beginnings to its self-realization (for a time), in the context of empire.

To speak of the development of the field of comparative theology with attention to Catholic roots in recent centuries is in part to rehearse 


\section{Francis X. Clooney, SJ}

Catholicism's own narrative of how Catholic tradition has worked from the beginnings of the Church until now: that history has always been an interreligious history. In a sense, the history of the Church is conducive to comparative theology. But we must both hear this self-account and consider it with some skepticism.

But first, a few words are in order with respect to the general background in which an open, interreligiously attentive Catholic theology might arise and flourish. The Catholic tradition adheres to the view that the world is essentially good. Nature speaks of God, and cultures, too, in their essential goodness speak of the divine, a truth and beauty that are never entirely obscured. The proper disposition is to expect to find the divine everywhere. The Catholic tradition is full of examples of how confessional commitments provide a solid base for noting the presence of God in the world around us, times and places rich in at least implicit epiphanies of Christ. The tradition of Logos theology attests that God's word and wisdom are everywhere implicit in the human reality, which is therefore intelligible and accessible to reasoned inquiry. Seeds of the Word are scattered, nonsystematically, in all the world's traditions.

The expectation that the Logos is discernible, if not everywhere, nevertheless in places near and far from centers of Christian culture, and thus at work and to be discovered amid the cultures of the world, may be taken also to highlight the characteristic rational current of Catholic tradition, a tendency that encourages both conversation and argument. Cultures and religions are intelligible, commensurable, and open to intelligent and spiritually meaningful exchange. This openness - instantiated again and again throughout history - is in turn accompanied by a more focused and narrow confidence that one can sort out the good from the bad, highlighting what is productive while refuting what one judges to be inadequate. Broad-ranging intellectual inquiry facilitates the maturation of the faith, even as it provides the conditions for apologetics, which at times lapse into polemic. Missionaries through the ages have been energized by various forms of the expectation that we can, with discernment, find God already present in the other. The Church is, briefly put, catholic as well as Catholic in both its dispositions and in its metaphysical and epistemological expectations.

The Catholic sense of sacramentality is also germane here, at least intuitively, because the idea that particular things and actions can be sites of the sacred opens the way for a deep reverence for reality as a whole. Versed in sacrament and liturgy, Catholic tradition fosters the dispositions by which one can recognize the presence of God in the particulars of other traditions, in the holy manifest in certain times and places. For Catholic tradition is thoroughly liturgical: words are never merely words, books never merely books. Rather, what we learn is enacted in Church and world, and by analogy, interreligious learning, even as a form of study, is always more than "merely" reading a book. The expectation of finding God in all things has a materiality and concreteness to it. There is, to put it simply, a catholicity 
to the Catholic view of the world that, doctrinal and ecclesial restraints notwithstanding, has nevertheless allowed the Catholic tradition to learn interreligiously over and over again.

Such dispositions open the way to learning, intended or unintended, in which whatever the doctrinal limits may be, but there is also there is fluid exchange across cultural and even religious boundaries. But such exchange also indicates, on a practical level, the probability of apologetics: we can argue the truth with them, showing the rationality of the Christian and the irrationality of systems that clash with the Christian. Openness and argument go together. All of this creates a frame in which comparative theological learning, as comparative and theological, is possible and religiously significant.

\section{Edifying examples}

The story takes on new life and significance in the Middle Ages, as the maturation of the great Catholic theological traditions of the West learn to anticipate and experiment in receiving wisdom from traditions outside the West. An intensely Catholic commitment to reason and to the Catholic faith as universally true and locally realized has quite often been productive of interreligious learning. Thomas Aquinas (1225-1274) is one of the supreme explicators and defenders of Christian doctrine in the history of Christianity, and at times he had hard things to say about non-Christians. No surprise. But as David Burrell showed decades ago (e.g., Burrell 1986, 1993), Aquinas also was an avid reader of Aristotle, as made available to the Christian West by Arab Muslim writers. He engaged in thinking through and arguing with Aristotle and his Arab interpreters, while likewise engaging and arguing with Jewish thinkers such as Maimonides. Aquinas's mind was capacious, to be sure, but there seems to be little evidence to sustain the view that he would have been more intellectually open had he a looser, permeable sense of doctrine: his quest for a right understanding of God's world led him to be open to truth wherever it was to be found. Nicholas of Cusa (1401-1464), a cardinal of the Church, plumbed deeply the mysteries of Christian faith in his brilliant philosophical and theological writings, and in works such as De Pace Fidei and Cribratio Alkorani he was also an extraordinary pioneer in imagining the conditions for interreligious learning, and how such learning might proceed, by way of the actual study of texts such as the Qur'an. Seen from the vantage point of the twenty-first century, this medieval learning was modest, fraught with misunderstandings, and less open than it might have been. But the thrust of this learning, grounded in a Christian commitment to the truth of reality and the truth of the faith, models the substantive and tough interconnection of faith and reason for which I have been arguing. ${ }^{1}$

In early modernity, the Catholic story went global in a new way. The support walls of faith and convictions regarding the narrow gates to salvation 
structured homes from which the early Jesuit missionaries in Asia (if I may stick to examples I know well) into a very creative learning wherein mission and intellectual openness fueled one another. ${ }^{2}$ Francis Xavier (1506-1552) was certainly negative toward other religions but nevertheless found himself having to learn to deal with cultural differences, precisely to continue the missionary work he felt himself obliged to: mission drove him to cultural experimentation, as when he re-presented himself for the sake of the learned Japanese leaders he wished to influence. Roberto de Nobili (1579-1656) re-created himself, as it were, in the course of his mission in south India. He changed his dress and customs, mastered the Tamil language, and sought ways to express the faith in accord with Tamil ways of moral and religious thinking. ${ }^{3}$ He was steadfastly critical of idolatry and harsh in finding moral depravity in Hindu mythology, but he did not abandon his intellectual project. Rather, he combined selective openness and selective negativity.

But not all missionaries are alike. An interesting contrast can be made with a Jesuit several centuries later. Constantine Beschi, SJ (1680-1747), also working in south India, did not disown Catholic doctrine, but in the potent chemistry of missionary fervor and a sense of the need for a new way of presenting the faith, he turned out to be a creative writer who could freshly re-envision the faith. He mastered the Tamil language and studied its literatures, among those a marvelous and unparalleled epic, Tempāvani (The Unfading Garland), which tells the story of the Incarnation - and much of the Bible - in high Tamil poetry, and from the perspective of St. Joseph. His turn to the literary provided him ways to re-express the faith without hammering it home and without giving it up. Yet he is the same Beschi who argued vociferously with the nearby Lutherans. His catechetical writing - for example, the Manual for Catechists - is primarily about habituating people to the faith, rather than attacks on the Hindu. And even in the Tempāvani, a negative attitude toward the pagan can be seen.

The nineteenth century is a sobering caution to my optimism regarding the Catholic manner of openness, because it does not give us very good examples of Catholic interreligious learning. This may have been due to the defensiveness of a Church feeling itself to be threatened by the hostility of rationalism in a skeptical Europe. Every claim made in the missions about non-Christian religions had to be received and restated with a mindfulness of how this new knowledge would be used in Europe, where reports about the non-Christian world might variously aid or undermine Catholic faith. Typical of a defensive Church were the polemical works of scholar/ practitioners such as Leo Meurin, SJ (1825-1895) in Bombay (see his lecture, "God and Brahm"). In the West, Catholic writing was marginal to the developing fields of comparative religion and comparative theology was and primarily resistant to the swiftly changing intellectual cultures of the West. In the United States, Augustus Thébaud, SJ (1807-1885) wrote the weighty Gentilism and The Church and the Gentile World at the First Promulgation of the Gospel, a learned investigation of the origins of religions and 
their relationship to Christianity, which in retrospect seems more concerned about the West's encroaching rationalism than the pros and cons of actual interreligious learning. But more research needs to be done on the littlestudied Catholic attitudes toward interreligious learning in the nineteenth century.

We see the revival of a more nuanced yet still very Catholic view of other religions late in the nineteenth century. Interestingly, it was a convert to Catholicism who was instrumental in this new venture. William Wallace (1863-1922) ${ }^{4}$ rethought his Christian identity rather dramatically through his encounter with Hinduism and, as a result, became a Catholic and then a Jesuit. A staunch Catholic resentful of both Anglicanism and empire, Wallace turned out to be a vigorous Catholic defender of Hinduism against its detractors. He insisted that the next generation of Jesuits had to study Hinduism deeply, with the necessary linguistic tools in place. As a result of his efforts, there flourished in Calcutta in the early twentieth century a school of Jesuit Indology under the notable leadership of Pierre Johanns (1882-1955), Georges Dandoy (1882-1962), Robert Antoine (1914-1981), Pierre Fallon (1912-1985), and Richard de Smet (1916-1997). Johanns and Dandoy cooperated in the famous "To Christ through the Vedānta" essays, published serially in The Light of the East. Here, too, we see formidable learning, harnessed for the sake of understanding positively major streams of Hindu intellectual thought, yet by the measure of the theology and philosophy of Thomas Aquinas, which provided both narrow restraints and a defining focus for new learning. Their commitment to Aquinas provided a coherent frame and confidence that progress in an interreligious theological understanding could be achieved; perhaps they would have been more open-minded without reference to Aquinas and the tight hold of Thomistic thinking, but more likely they would not have undertaken such study at all.

We might continue this exploration by paying attention to still other figures who can be honored as icons of the prehistory of comparative theology. I have in mind figures such as the innovative contemplatives Jules Monchanin (1895-1957) and Henri Le Saux (1910-1973). In the late 1940s, in deep south India, they founded the Saccidananda Ashram (Abode of Being, Consciousness, and Bliss), which came to be known more popularly as Shantivanam. Both took very seriously the truths of the Catholic faith and would not discard them. Confident in the adaptability of their Catholicism, however, they sought to free it of its Western cultural baggage in order to reimagine Christian contemplative life, and deeply root it, as they said, in Indian soil. Each in his own way delved deeply into Vedānta and Hindu texts, seeking both to find Christ in the mystery of Hindu spirituality and to rediscover Christ through Hinduism. Their struggles, intellectual (in finding common ground between Hindus and Christians), spiritual (in becoming intimate to Hindu learning in its depths while still a Christian), and practical (in setting up and maintaining the ashram), characterize them as persons; were they not Catholic, they probably would not have come to India at all. 


\section{Francis X. Clooney, SJ}

Monchanin and Le Saux would not have labeled themselves comparative theologians; they feature what are virtues necessary to the work of comparative theology: sustained study and doctrinal commitments, yet without letting Christian doctrines turn into the tools of a priori judgments about other religions. Here it suffices to say that these figures represent nicely the holistic nature of modern Catholic learning, such as that which infuses comparative theology. Of course, similar representations of the roots of comparative theology might be set forth with respect to other parts of the world as well.

We can also think in this regard of Thomas Merton (1915-1968), whose sustained and deepening interest in other religions remained even to the end in service to the renewal of Christian contemplative identity. Raimon Panikkar (1918-2010) deserves attention too, as a figure whose experience and aspirations are closely aligned with the work of comparative theology. In his own signal fashion he brings together the riches of Hindu and Christian traditions, transforming his own religious identity in the process. His "imparative theology" reflects some of the same confidence and hope, and commitment to reading practices, that inspires comparative theology.

In the twentieth century, we witness more Catholic scholars coming to the fore and contributing to comparative study outside the mission fields. Here I can mention just a few of the notable figures. The twentieth century abounds in figures who exemplify Catholic learning at its best. Louis Massignon (1883-1962) was a seriously committed Catholic even as he became one of the greatest scholars of mystical Islam. ${ }^{5}$ Henri de Lubac (18961991), ${ }^{6}$ no theological pluralist, silenced by the Church in mid-career but later in life in a position of rejecting the honor of becoming a cardinal of the Church, studied Buddhism in some depth. He went far beyond the needs of apologetics, determined as he was to find a way of connecting its wisdom with Christian revelation, casting it as a highest form of natural questing for what had been given to Christians fully as God's gift. We can also think in this regard of Thomas Merton (1915-1968), who sought to deepen Christian identity in and through bold interreligious openness. ${ }^{7}$

And so on. Such examples could be multiplied and must be deepened beyond this series of honorable mentions, but my point is precisely to evoke an array of witnesses: learned, believing Catholic Christians who also crossed boundaries and learned interreligiously. None of these figures was doing precisely the work we need to do today, in part because our attitudes and expectations (regarding both Christian and non-Christian) have changed, and in part because they, like us, were ever responding to the particular historical moment wherein their thinking and writing took shape. But possessed of very strong religious convictions, they managed to exemplify serious interreligious learning and creative engagement across religious borders, and thus exemplify the style of being Christian that is still needed today. 


\section{On doctrine}

We must now step back and take a closer look at the foundations of this tradition of real and persisting openness. The examples in themselves are telling: that these figures are all Catholic merits some further consideration if the point is to be more than anecdotal and inspirational. All these figures, from the early Church up to contemporary Catholic thinkers engaged in interreligious learning, worked within a clear doctrinal frame, engaging in truths not of their own making. I suggest that if we understand doctrine properly, we will not be inclined to think them better off had they left doctrine behind.

The theological texts most worth reading are those written with both seriousness and humility, respectful of the power of words that direct our attention to truth and urge us to think and judge after our minds have conformed to that truth. The combination of faith - its doctrinal formulation clearly asserted and stubbornly held so as to be productive of inquiry, not stifling of it - remains potent. Doctrinal words can work, provided they do not draw attention to themselves and in that way become obstacles.

The relation of words, learning, and doctrines - and claims of truth - of course remains complex, and an adequate assessment of doctrine is well beyond the scope of this small chapter. Even if the broad lines of doctrinal claims are clear in creed or catechism, new information constantly and properly upsets settled ways of learning, while explanations that aim at smoother understanding inevitably end up complicating things in new ways. Making doctrine meaningful and fruitful is never a matter of mere application, but rather the discovery of a creative ground. This careful compounding of faith and understanding - inquiring faith, humble understanding - has its own intensity. It drives a truly open search that brings commitments and doctrines, dearly held, into contact with what is true and holy in other traditions, precisely because (in many cases) such doctrines are seen to be competing for the same space. As a result, there is always new work to be done, to make sure that our words, individual and communal, do not drift away into side issues near or far. But this ought not distract us from the work of study. The solution is not the abandonment of doctrine, but a more careful use of doctrine to open up a perspective on the world rather than closing it down.

Wesley Hill's reflections on the purpose of creeds sheds light on the power of careful, insistent, yet humble writing with respect to realities beyond words:

The Creed safeguards the mystery and wild freedom of God; it does not box it in and tame it. The point of the Creed isn't that its words are satisfactory. It's that those words refuse our inveterate preference for premature theological satisfaction. 
Doctrinal reflection is not so much a matter of making things perfectly clear as instead ruling out bad alternatives that drain our words of God's mystery:

Approaching Jesus in this way [attentive to doctrine] turns language back on itself, exposing our poverty. Confessing what is beyond language, the creeds use the words least likely to diminish the mystery while at the same time gesturing at its depths. To say otherwise, to reject the Creed as so much rationalist mystery-refusal, is to get things exactly backward. It is the Creed, not the heresies it proscribes, that dares to confess God in Christ uncontainable, unclassifiable, and incomprehensible.

(Hill 2016, 16)

The words I have italicized serve us well interreligiously. The disciplined words of creedal statements do not block the path to interreligious learning, but inculcate virtues of mind and heart that direct us properly toward the mystery of our own tradition and, I suggest, the mystery of the other as well. Without doctrine, we have no guarantee that we will simply be "more open," because we might just as well become directionless, aimless.

Truth in its doctrinal form focuses inquiry, helping inquiry to avoid losing its way and ceasing to be real interreligious learning. A serious commitment to the truths of religious traditions can guide interreligious learning. This is so if we do not make too much of our carefully chosen words. We would be foolish to reduce the mystery of God to what we can say about it by the best words of theologians. But we would not be better off were we to decide that our encounter with truth is better fostered by leaving behind even the positive doctrines of traditions, as if unlimited verbal and mental fluidity would be a better base for taking other traditions seriously. ${ }^{8}$

These reflections on doctrine are implicitly couched in Christian terms. But this disciplined and even austere attitude toward our words and the received truths of received faith claims applies also to thinking about the truths of the Hindu traditions we encounter in great Hindu theological texts. Non-Christian masters of theology also know that words must be used skillfully and without inflated importance, crafted so as to disencumber the reader, put aside wrong ways of reading and using words: very specific and rigorous rules for thinking, reading, and writing at the service of formulating a correct view of the world. Hindu thinking, for example, will not be driven by a Gospel imperative, but there are pertinent and parallel universalizing trajectories in Hindu thought that both drive and constrain Hindu views of the religious other. ${ }^{9}$

\section{Vatican II's opening up of a Christ-grounded space}

A Catholic grounding for interreligious learning is not merely a wish, detached from the harder realities of the Church. The Catholic attitude 
I have been presenting thus far is in harmony with the direction of Church teachings today. ${ }^{10}$ Vatican II (1962-1965) in particular opened up new space for a Catholic interreligious learning, and in the typically Catholic way that combines depth, focus, and a consequent openness. ${ }^{11}$ Though not all the conciliar statements were equally interreligiously open, Nostra Aetate, approved in the last session of the Council, turned out to be most capable of showing a way to learn from the religious other. Here is the key text from n. 2 of the document:

The Catholic Church rejects none of the things that are true and holy in these religions. She regards with sincere attentiveness those ways of acting and living, those precepts and doctrines which, though differing in many aspects from the ones she holds and sets forth, nonetheless by no means rarely reflect the radiance of that Truth which enlightens all people.

This is a limited openness, a nonrejection of the true and holy, rather a full embrace of Hinduism and Buddhism, but it is a deeply founded positive regard for other traditions. The images of light refer to John 1.9, which presents Christ as light and truth: "The light shines in the darkness, and the darkness did not overcome it. ... The true light, which enlightens everyone, was coming into the world" (Jn 1:5, 9). This is a matter of the light of Christ, not a generic light, and it shines from within the religions, not as a harsh light of judgment on them.

The next statement draws explicitly on John, and it can be read so as to serve to undergird and justify, rather than narrow, the deep reverence with which Catholics are to approach religious traditions:

Truly she announces, and ever must announce Christ "the way, the truth, and the life" (Jn 14:6), in whom humans may find the fullness of religious life, in whom God has reconciled all things to Himself.

(2 Cor 5: 18-19)

This text may be read as very narrow: only Christ. But I have always found it to be rather universal in disposition: wherever there is truth, Christ is there; wherever people are on the way to God, Christ is there; where people are fully alive, Christ is there, not as an add-on, but as deep within the truths, ways, and lives of people of all traditions and none.

What is notable, too, about Nostra Aetate n. 2 is its lack of a priori judgments and already-settled conclusions about what other religious traditions are to mean. Study and inquiry are necessary. It stands exceptionally on a middle ground, neither conservative nor liberal, free of many of the theological constraints and a priori conditions common to the other documents, and yet without stepping away from Christian commitments. Written in the space of dialogue, expecting to be read by people of many faith traditions, 
it stands open and receptive in the presence of the other, expecting listeners and hence conversations rather than monologues, true learning rather than confirmations of what we already know. It is the harbinger of a new era of the Church and a new Catholic style in the world.

The authors of Nostra Aetate were not independent operators, unaware of or unsympathetic to the cautions posed in other documents of the Council, and a Catholic cannot choose merely the parts of documents she or he likes. Still, this declaration shifts from talking about to inviting listeners to learn something: listen, find, learn. Christian witness remains essential; it is possible because Christ is the way, the truth, and the life; it is this witness that indicates respect for and openness to all that is true and holy in the world's religious traditions, illumined by the light of Christ shining from within. In a sense, Nostra Aetate sets for the entirety of Vatican II documents their interreligious application: how they are to be used in our era.

The Council and its forward-looking daring prompted fresh thinking interreligiously by Catholic theologians, with many figures daring to chart new paths forward. By my judgment, the soundest strand has been that of the new, post-conciliar inclusivism, promoted in an incipient fashion by Karl Rahner (who did not study other religions) ${ }^{12}$ and then most famously by Jacques Dupuis. This project, not so much as "-ism" as an "including" theology, has been dedicated to achieving a balance between fidelity to tradition and the core revelation of Christian faith - in Christ, in the mystery of the Trinity - on the one side and, on the other, a radical openness to God at work in the world, in Christ, in the Trinitarian dynamic, particularly that of the Spirit. ${ }^{13}$ The hard edge of such work, of course, lies in a refusal to give up on doctrine for the sake of an idealized complete, unlimited openness to everything.

Monsignor John Oesterreicher, a convert to Catholicism from Judaism who was a leading figure at the Council and thereafter, reflected as follows on Nostra Aetate:

We must not be satisfied with some general knowledge of them [i.e. non-Christian religions]; the Declaration rather demands a deeper knowledge of the ways of God and men. The more we penetrate into the convictions and religious practices of non-biblical origin, the more we shall perceive God's gentle, almost shy action everywhere. . . . It is the greatness of those sections of the Declaration dealing with the various non-Christian religions that they praise the omnipresence of grace.

(Oesterreicher 1967, 93)

This is the inquiring spirit that motivates much comparative theology as well.

Here, too, it would be disingenuous to be ignorant of limitations and counterexamples. How doctrine is used is unsurprisingly varied, and not every usage facilitates openness. The conservative authors of Dominus Iesus 
(2000), the document from Rome's Congregation for the Doctrine of the Faith, were determined to rein in Catholic speculations on pluralism, binding very tightly together Creed, Gospel, Church, and salvation, all in the light of Christ, and for this purpose the declaration became a handy litmus test for orthodoxy, and unfortunately a set of justifications for not actually engaging in interreligious learning and for rejecting insights gained interreligiously..$^{14}$ Still, the Creed remains the bedrock for many, if not most, of the constructive Catholic theologians who engage in interreligious learning in a faithful and open manner and likewise do comparative studies. That there are truths of faith grounded in scripture and tradition, truths regarding God, Christ, the Spirit, the world, and the Church, enables those of us committed to interreligious openness to be open and yet maintain and refine ever more definitely a frame within which to receive and welcome the religious other. This delicate balance is deeply indebted to a robust understanding of the Trinitarian God.

\section{Walls yes, and with door and windows that open}

The paradox of a strong version of Roman Catholic doctrine and practice, instantiated always in the lives of Catholics who did learn interreligiously, has to do with the rigor and boundaries of the tradition and its simultaneously adaptation, over and over again, to new circumstances: the Church is in a position of having constantly to modify itself globally because it is dedicated to the good news of God's kingdom; it can be fruitfully open, ever on the edge of crossing sanctioned borders, because it has borders and limits and works only with a sense that God has already been present in the Church, as it has already been. But this focused-open dynamic makes sense. Religions are not like properties with boundary markers, fences that keep people in or out. They are places in which to dwell, houses, homes. These have walls that making dwelling within them possible. One doesn't remove the walls if one wants to dwell there. Rather, we seek to ensure by the use of windows that light and fresh air can enter and by the use of doors that dwellers in the home can go out and come back.

I have thus far said nothing about "Theology Without Walls," even if, by contributing to this volume, I am hoping to make evident my respect for Jerry L. Martin's best instincts regarding openness while resisting his way of putting it. I am suggesting that we do well to pay closer attention to how traditions work and, in this instance, how Christian tradition works. If we do, we come to see that walls need not, should not, be torn down, because doing so would be in danger of removing the very support walls that make religions able to be robustly universal. I therefore distance myself from the particular framing of the project as Jerry L. Martin puts it:

Often theology is defined as the articulation of the beliefs about the divine reality within one's own tradition. In light of the widespread 
experience of finding spiritual insight in other traditions as well, that definition seems inappropriately limited. Surely, the aim of theology should be to learn all we can about ultimate reality, regardless of the source of the insights. Even comparatively theology, when it is regarded as finally confessional, limited to asking what light other traditions throw on my own, stops short. What is needed is a Theology without Walls, without confessional boundaries, without blinders, as it were. That does not mean that we do not stand somewhere, but that our sense of our goal is not limited to where we stand at the outset.

I therefore rewrite Jerry's words like this:

Often and rightly theology is defined as the articulation of the beliefs about the divine reality within one's own tradition and from there, outward into the world around us. In light of the widespread experience of finding spiritual insight in other traditions as well, that definition may seem inappropriately limited, because it fails to indicate more directly how the articulation of beliefs also reaches out to other traditions. Surely, we see now that the aim of theology should be to learn all we can about the revealed truths of the faith, without confusing the insights with any particular cultural framing of them. Even comparative theology, which is confessional at the beginning and end, does well to explore what light other traditions throw on my own, so as to change my relation to my own tradition, without denying the roots of that tradition and without reducing the religious other merely to an instrument of self-improvement. It does not stop short for the sake of a hoped-for unrestricted openness. What is needed is a theology with walls, a home with foundations and walls and windows and doors, a roof held up by the walls and - why not, a welcome mat at the entrance.

\section{Notes}

1 For a thoughtful, though guarded, assessment of Cusa's approach to pluralism, see "Nicholas of Cusa's De pace fidei and the Meta-Exclusivism of Religious Pluralism" by Aikin and Aleksander (2013, 219-235).

2 I choose here simply several of the Jesuit figures I have read in recent years and without prejudice against the fact of other Catholic and Christian instances of creative interreligious adaptations.

3 On de Nobili's real but limited openness, see Clooney (2007, 51-61).

4 See my essay, "Alienation, Xenophilia, and Coming Home: William Wallace, SJ's From Evangelical to Catholic by Way of the East" (Clooney 2018a, 280-290).

5 See Krokus (2017).

6 See Grumett and Plant (2012, 58-83).

7 On Merton, see my essay, “Thomas Merton's Deep Christian Learning Across Religious Borders" (Clooney 2017, 49-64).

8 I have spoken of the use of words in crafting "liberating doctrines." But the pointsubmission to tradition, focus, particularity as a base for universality - illumines 
also the value of rituals, particular sacramental rites that significantly open up perspectives on material and human realities without restriction, and likewise the value of strong communities with defined identities that have the resources to support venturing forth, learning from the other, and substantive returns home: these help ensure openness, rather than thwarting it.

9 See Clooney (2003). Also guest editor of this thematic issue.

10 I must, however, leave aside here the many controversies among Catholics today about the true legacy of Vatican II.

11 See my essays, "How Nostra Aetate Opened the Way to the Study of Hinduism" (Clooney 2016, 58-75) and "Nostra Aetate and the Small Things of God" (Clooney 2018c, 305-316).

12 See Rahner (1971, 161-177).

13 See Dupuis (2002), Heim (2000), and a recent essay of mine explaining how this including theology works as the desired alternative to pluralism: "Fractal Theory, Fractal Practice: Theology of Religions, Comparative Theology" (Clooney 2018b).

14 For a balanced set of assessments of Dominus Iesus, see Pope and Hefling (2002).

\section{References}

Aikin, Scott F., and Jason Aleksander. 2013. "Nicholas of Cusa's De pace fidei and the Meta-Exclusivism of Religious Pluralism." International Journal of the Philosophy of Religion 74: 219-235. doi:10.1007/s11153-012-9367-0

Burrell, David B. 1986. Knowing the Unknowable God: Ibn-Sina, Maimonides, Aquinas. Notre Dame, IN: University of Notre Dame Press.

Burrell, David B. 1993. Freedom and Creation in Three Traditions. Notre Dame, IN: University of Notre Dame Press. doi:10.1017/s0034412500019648

Clooney, Francis X. 2003. "Hindu Views of Religious Others: Implications for Christian Theology.” Theological Studies 64 (2): 306-333. doi:10.11 $77 / 004056390306400204$

Clooney, Francis X. 2007. "Understanding in Order to be Understood, Refusing to Understand in Order to Convert." In Expanding and Merging Horizons: Contributions to South Asian and Cross-Cultural Studies in Commemoration of Wilhelm Halbfass, edited by Karin Preisendanz, 51-61. Vienna: Austrian Academy of Sciences Press.

Clooney, Francis X. 2016. "How Nostra Aetate Opened the Way to the Study of Hinduism." In Nostra Aetate: Celebrating 50 Years of the Catholic Church's Dialogue with Jews and Muslims, edited by Pim Valkenberg and Anthony Cirelli, 58-75. Catholic University of America Press. doi:10.1353/acs.2018.0002

Clooney, Francis X. 2017. “Thomas Merton's Deep Christian Learning Across Religious Borders.” Buddhist-Christian Studies 37 (1): 49-64. doi:10.1353/ bcs.2017.0005

Clooney, Francis X. 2018a. “Alienation, Xenophilia, and Coming Home: William Wallace, SJ's from Evangelical to Catholic by Way of the East." Common Knowledge 24 (2): 280-290. doi:10.1215/0961754x-4362469

Clooney, Francis X. 2018b. "Fractal Theory, Fractal Practice: Theology of Religions, Comparative Theology." In Incarnation, Prophecy, and Enlightenment, edited by Paul Knitter and Alan Race. Maryknoll, NY: Orbis Books.

Clooney, Francis X. 2018c. "Nostra Aetate and the Small Things of God." In Catholicism Engaging Other Faiths: Vatican II and Its Impact, edited by Vladimir 


\section{Francis X. Clooney, SJ}

Latinovic, Gerard Mannion, and Jason Welle, 305-316. London: Palgrave Macmillan. doi:10.1007/978-3-319-98584-8_18

Dupuis, Jacques. 2002. Toward a Christian Theology of Religious Pluralism. Maryknoll, NY: Orbis Books.

Grumett, David, and Thomas Plant. 2012. "De Lubac, Pure Land Buddhism, and Roman Catholicism." Journal of Religion 92 (1): 58-83. doi:10.1086/662206

Heim, Mark S. 2000. The Depth of the Riches: A Trinitarian Theology of Religious Ends (Sacra Doctrina: Christian Theology for a Postmodern Age). Grand Rapids, MI: Wm. B. Eerdmans Publishing Co. doi:10.1017/s0360966900009919

Hill, Wesley. 2016. “God's Strangeness.” First Things 259: 15-16.

Krokus, Christian. 2017. The Theology of Louis Massignon: Islam, Christ, and the Church. Washington, DC: Catholic University of America Press. doi:10.2307/j. ctt1p6qppr

Oesterreicher, John. 1967. "Declaration on the Relationship of the Church to NonChristian Religions." Commentary on the Documents of Vatican II 3: 93.

Pope, Stephen J., and Charles Hefling. 2002. Sic et Non: Encountering Dominus Iesus. Maryknoll: Orbis Books. doi:10.1017/s0360966900000293

Rahner, Karl. 1971. "Anonymous Christianity and the Missionary Task of the Church." Theological Investigations. trans. David Bourke. London: Darton, Longman and Todd. doi:10.1017/s003441250000648x 